\title{
Financial Administration between Centre and State in India - A Review Paper
}

\author{
Dr. Kuldeep Walia \\ Assistant Professor \\ Sri Guru Granth Sahib World University \\ Fatehgarh Sahib, Punjab, India \\ E-mail:kuldeepmani9@gmail.com
}

In a federal set up, the effective working of the whole system is fundamentally contingent upon perfect understanding, co-operation and coordination between the federating units of the government.In addition to text books on the subject of Public Finance I have been able to review following studies so as to develop an insight on the subject relating to various aspects of the financial relations between Union government and State governments in India.

B.S. Grewal, in his book Centre-State Financial Relations in India has done economic evaluation of fiscal federalism in India. The book mainly analysis the policies of the Planning Commission and the Finance Commission. He has tried to find out the steps by which fiscal federalism in India has strayed from its economic goals and has gradually shifted towards increasing adhocism. He has mainly dealt with revenue side and that too transfer of resources from the Union government to the State governments.
In the beginning he has reviewed the principles of inter-governmental financial transfers for plan purposes, non-plan purposes and discretionary transfers and has concluded that the transfers recommended by the Finance Commission are and should continue to be general and unconditional. Any scheme of general transfer has to be guarded.

P.K. Bhargava in his book Essays on Indian Public Finances has complied some of the articles written by him from time to time. These papers mainly deal with important problems relating to Centre-State financial relations, agricultural taxation, sales taxation, resource mobilization by the states, etc. He has not dealt with all the issues in an integrated from but has made general observations with regard to the growth of revenue and expenditure with in the Indian situation.

Sanjaya Basu, in a write up in Economic Times says that "constitutional structure has been 


\section{International Journal of Computing and Business Research (IJCBR) \\ ISSN (Online) : 2229-6166 \\ International Manuscript ID : 22296166V7I2201702 \\ Volume 7 Issue 2 July - August 2017}

so evolved that it is the State Governments which have been burdened with a bulk of developmental work, apart from the provision of infrastructure and welfare, while their control on fiscal resources has weakened" ... He also tells that what the Centre devolves to the states, excluding loans and grants, are the State's constitutionally defined and rightful share of Centrally collected revenue. The State's own deficit must be calculated after their share of Central revenues have been added to the State's revenue.

In similar article in Economic and Political Weekly, KalyanRaipuria reviews the sustainability of the financial transfers to the States through the Finance Commission, Planning Commission and through other government departments. And has observed that parameters with which transfers have to take place as given by the constitution (institutional bases, resources imbalance, and the slower growth in the face of large development requirements required assistance for unforeseen situations and natural disasters etc.) need revision. He further points out that "total resources transfers to States and Union Territories in recent years have been around 40 per cent of the total receipt of the Centre. The less developed States getting relatively larger share (and still not satisfied) and relatively developed states have shown their concern about the decline in their share in the total". He refers to various suggestion made by different reviewers and suggests that the basic issue is how the level of grants unrelated to emerging growth and inflation and can really serve the purpose, and if specific problem - related grants would not be preferable to block Finance
Commission and Planning Commission transfer together should be made in isolation, particularly because of rising dearness allowances liabilities; constrained mobilization of small savings to supplement own resources; limited scope for mobilizing borrowings from the deposits of the banking sector; and possibility of rising imbalances in miscellaneous capital receipts (MCR) due to expected increase in debt payment liabilities and low recovery of advances made by minimum requirement of financial transfers to the States are likely to be quite larger in future.

In an Article, "Does the Indian Tax Policy Have a Rationale", K.B.K. Rao has observed that in spite of the numerous changes the Indian tax structure could not acquire the requisite stability with revenue stability.

Adolph Wagner is of the view that the level of government expenditure changes according to the given historical situation, economic situation and economic structure and development. For example, he relates public expenditure with population growth and transportation needs.

Peacock and Wiseman, in a very popular study examine the time pattern of public expenditure there are other aspects of the developments of public expenditures, such as the time pattern of public expenditure growth which seems to be equally significant.

G.S. Lall in his look Public Finance and Financial Administration in India has very lucidly explained Union State fiscal relations in India, 


\section{International Journal of Computing and Business Research (IJCBR) \\ ISSN (Online) : 2229-6166 \\ International Manuscript ID : 22296166V7I2201702 \\ Volume 7 Issue 2 July - August 2017}

problems which may arise with the working of fedral finance, how these problems can be solved and what basic principles should be observed so as to avoid any conflict, to what extent Indian federal system has been able to avoid conflicts, to what extent distribution of financial resources between Union government and States i.e. fedrating units is correct, Author has also explained at length the general Principles of financial Administration, how budgets are prepared, what is the role of legislature in the preparation of the budgets how budgets are executed and what is the role of Audit in the system of government accounts etc.

H.L. Bhatia in his book Public Finance has discussed very elaborately both the theoretical and applied aspects of public finance in the context of the Indian institutional framework. The authority also examines Indian federal finance, public debate in India and also other related aspects of the India public finance.

D.T. Lakdawal in his book Union State Financial Relations has very critically analyzed the working of federal finance in India and has also reviewed the recommendations of various Finance Commissions.

Thus the federal Constitution must provide such as in-built mechanism that the federal harmony and co-ordination is continuously maintained. The prime cause of misunderstanding or suspicion in federal countries is usually on account of some unsatisfactory financial arrangement between the federating units of the government. It is, therefore, important to define precisely the financial powers of the different layers of government. A satisfactory arrangement of transfer of resources must also be evolved so that federal relations are not disturbed.

\section{References}

1. B.S. Grewal, Centre State Financial Relations in India, Punjabi University, Patiala, 1975.

2. P.K. Bhargava, Essays on Indian Public Finances, Chugh Publications, Allahabad (India), 1978.

3. Sanjaya Basu, "The Step Child for Too Long (State Finances)", The Economic Times, 26th April, 1993.

4. KalyanRaipuria, "Financial Transfers to States Issues and Outlook", Economic and Political Weekly, December 5, 1992.

5. K.B.K. Rao, Economic and Political Weekly, December 5, 1992.

6. Adolph Wanger, in R.A. Masgrane and Abour T. Peacock (Eds.), Classics in the Theory of Public Finance, Internal Economics, Association, Macarnillan and Co. Ltd., London, 1958.

7. Peacock and Wiseman, the Growth of Public Expenditure in the United Kingdom, A study by the National Bureau of Economic Research, London, Oxford University Press, 1961.

8. G.S. Lall, Public Finance and Financial Administration in India, JPJ Kapoor and Co., New Delhi, 1976.

9.H.L. Bhatia, Public finance, Vikas Publishing House Pvt. Ltd., New Delhi, June, 79.

10. D.T. Lakdawala, Union State Financial Relations Lalwani Publishing House, Bombay, 1967. 